B. Referate zum Problem der Hyperkoagulabilität in der Gestation

Gynaecologia 1968;166:19

\title{
Uterasnekrose bei Cumarin-Therapie
}

\begin{tabular}{|l|l|}
\hline $\mathrm{H}$. & Haefeli \\
\hline
\end{tabular}

Universitätsfrauenklinik Basel (Dir.: Prof. Dr. Th. Koller)

Die Publikation erfolgt später. 